\title{
PLANT FORM SCULPTURE AT TRANSIT HUBS, 1991-2010
}

\author{
R. G. WAKELAND, ART HISTORIAN
}

\begin{abstract}
To show public transit unified with natural world symbolism, five outdoor sculptures in transportation networks are photographed and shown situated within their site plans. Spanning space, they alter the landscapes of their multimodal stations, while invoking sublime nature. Denver, Colorado; Irving, Texas; Garland, Texas; Los Angeles, California; and Vancouver, British Columbia are the locations. Integrated with each street scene, botany becomes a common vernacular. Conversations about history, shelter, inter-cultural discourse, bicycling, and respite oases unfold. As indicia of public engagement, a review of public records investigates funding sources, selection processes and methods. Variations emerge, among which delegated committees, project architects, contractors, and public-private collaborators make decisions.

Keywords: Multimodal transportation, plant form, public art, sculpture.
\end{abstract}

\section{INTRODUCTION}

From the park and ride lots at the transit hubs stretch millions of miles of highway, upon which most commuters depend. Sentiment to restore natural beauty to acres of asphalt paving and to transform the landscape of the transportation hub resides in these sculptures. While clutching our electronics, today we gasp and grasp for the waterfall. Station structural design, surrounding landscaping, and art are unified. Herein the plant forms emerge via public consensus among multifarious stakeholders, not as unilateral artists' inspiration.

\section{SOLAR BIKE TREE, VANCOUVER, BRITISH COLUMBIA, CANADA, 2010}

The solar bike tree sculpture (Fig. 1) rises as a vertical in line with the trees in planters which form an arch along the pavement bordering the waterway. Its location marks the junctions of three city bicycle paths, and it serves as a parking lot for 15 bicycles. Within wooded parks and along the seawall, extensive bicycle paths navigate throughout the city. Bicycles are encouraged on other public modalities, such as bus and train intersecting the bike paths. The city light rail stops across the street, serving the adjacent science world non-profit educational museum [1]. This locale represents a joint public-private destination attraction as in addition to it encompassing city land, the province of British Columbia owns the building itself [2].

The epitome of functionality and pragmatics, the bike tree fused low tech, high tech, and collaboration. To compensate for replacing a street light, a motion-sensor solar powered light was nested in the branches. This hardware, as well as wiring services, was donated. The powder-coated steel was fabricated locally, and certified by a structural engineer as a viable structure. City engineers gave input to the design. The city parks department removed the street light and poured the concrete slab base [3]. Vancouver Area Cycling Coalition (VACC) also contributed input on design by the artist [3, 4].

Notwithstanding mechanical prowess and solar panels, the solar bike tree is listed on Vancouver's public art registry [4]. An ad-hoc, revolving constituency committee of artists and citizens approved ideas according to available funds from city capital expenditure accounts. Through this process, Better Environmentally Sound Transportation (BEST) submitted artist Spring Gilliard's proposal for the solar bike tree. It was accepted in 2005. From there on, the artist negotiated with the city parks and science world for installation location (Fig. 2).

Through this negotiation, the design and construction meandered. Although authorized by the city park board, its final approval was contingent upon that of the non-profit organization which operates 
science world [2]. Government source documents imply an underlying, non-descript contentious process. While science world was purportedly 'a supportive and enthusiastic partner from the onset', artist angst surges throughout the delay and the innuendo that she 'worked closely with Science World and the Park Board to oversee the work' [3].

The solar bike tree was finally installed in January 2010, and furthered the city's commitment to bicycling as integral to intermodal transportation [5]. Since installation, the province, supported in part by the city, renovated the walkways and pedestrian pavement surrounding the bike tree. The construction comprised and facilitated wider ranging adjacent street improvements. Throughout this metamorphosis, the bike tree was left in place $[2,3,5]$. Like the growing trees lining the waterway curve, the bike tree situates the arbor form among the flat sea side pavement, within the human built environment.

\section{REUNION BUS SHELTERS, UNION STATION GATEWAY PLAZA, LOS ANGELES, CALIFORNIA USA 1996}

Glass and grey metal elevate this leaf (Fig. 2) above the bench below, which serves as a bus stop. Six such benches and leaves surround an oval exterior brick paved area at the east entrance to Union Station, Los Angeles, called Gateway Plaza. Union Station is an expansion of the original, historic train station [6]. Travelers now connect with city busses, regional busses, airport busses, Amtrak, and metro (subway) trains, among other modes. City busses circumnavigate the oval. The six leaves together create an arboretum atmosphere at the plaza; a poetic welcome and nostalgic farewell for airport bus passengers. The center of the oval opens to a subterranean pedestrian walkway, from which the Figure 2 photo was taken. A pedestrian bridge intersects the walkway at the plaza level.

The governing entity for Union Station, as well as city-county transportation, is and was at the time of Gateway Plaza construction, the Los Angeles County Metropolitan Authority (MTA) [7]. Original concepts for the plaza and subterranean walkway included a concert venue (by blocking off the oval to traffic), shops and cafes, with outside pedestrian circulation between station levels [8]. However, this never materialized, as presently there is no lower level subway entrance-exit, nor any outdoor shops. An interior, glass clad space fronts the plaza, and encloses stairs, escalators, and elevators. Thereby people circulate among the lower level subway concourse, the middle plaza street level, and above level administrative offices (east portal) (Fig. 2).

However, the subterranean walkway and plaza maintain their original inspiration to be an 'urban oasis' for 'respite, refreshment, and relaxation' [8], although most pedestrians, the writer observed, at the lower level were smoking. The sidewalks are wide, growing greenery abounds, and stone clad benches abutting the architecture serve waiting passengers. The walkway curves, evoking the river once free-flowing through the city [8]. Public art murals complete this environment. These curvilinear schemata continue in the leaves.

Although funded with public money, private entities were contracted in the process and records thus became inaccessible or were lost. No other records, besides those cited herein, were found responsive to the author's public records request [9]. Gateway Plaza was built in 1996 as Union Station's joint public-private redevelopment between MTA and Catellus Corporation. Within the 52-acre historic rail station, 12 acres were developed $[6,7,8]$. Another private corporation, directed by Tamara Thomas (now deceased) [10] and Fine Art Services, Inc., conducted indoor and outdoor public art competitions [11].

An undated Fine Art Services report lists Kim Yasuda and Torgen Johnson as partners for 'Union Station Gateway' bus shelters (among three art projects) [11]. The leaf sculptures and benches appear integrated with the plaza on Ehrenkrantz \& Eckstut architects' drawings (Fig. 2) [8], with no 
attribution to any artists. The architect drawings thus imply artist collaboration and consulting with the architects in the leaf sculptures and benches.

\section{MARKER TREE, DOWNTOWN IRVING / HERITAGE CROSSING STATION, IRVING, TEXAS USA 1991}

Sculpted stainless steel recreates the time immemorial signaling system of native people as a modern wayfaring sign for public transit. Along the $19^{\text {th }}$ century Birdville Trail running west from Irving, a historic site still exists of these trees [12]. To mark direction at a divergence or crossroad, native people bent a sapling, and anchored it with rawhide staked into the ground. The tree grew as an arc, marking the way. David B. Hickman received the US $\$ 48,000$ award for his proposal replicating these trees (Fig. 3). The tree was constructed of stainless steel, and the rope and stake anchoring it to the ground was of cast bronze [13].

Construction of the Trinity Railway Express (TRE) light rail extension to Irving in 1991 triggered funding for the sculpture. Converging multimodalities were a local bus transfer point, the rail station, bicycle parking, para-transit van pickup, and adjacent park and ride lot [13, 14] (Fig. 3). A percentage of the construction cost was appropriated for the sculpture. Connecting Irving with Dallas, Fort Worth, and the Dallas-Fort Worth airport, TRE fulfilled federal and state mandates for regional transportation [14]. Among this multimodal landscape, the marker tree was situated within the triangle of grass at the site's southeast edge, fronting the tracks.

Dallas area rapid transit (DART) was the TRE administrator. Following DART protocol, an art committee was nominated by the mayor, and launched its mission by consulting with station architects on station design. Finally, the committee chose the proposal drawing for the sculpture. Towards this end they adopted an artistic value statement emphasizing the town's historic commerce, trade routes, and associated economies [13]. As shown in Fig. 3, freight lines, moving on parallel tracks, contributed to this history, as they do today.

Native people's aboriginal exploration and resource exploitation were replicated by successive population incursions into the geography. While native people's paths followed game, European immigrants, Texans and American settlers came to farm. Horse and stagecoach trails served gold prospecting. The transcontinental railroad served a burgeoning industrial economy, transporting raw materials, natural resources, farm products, and the United States army. Many maps and tourist brochures illustrate this history, and were part of TRE's dossier on this art request for proposals [13].

The site design, pivoting on crossroads and junctions, connects via sidewalks to the historic preservation downtown area. Here, the 1903 auction lot site is commemorated. Additionally, the voters approved a city-county tax zone political subdivision to fund parks, trees, fountains, solar powered street lights, and other street infrastructure promoting historic district redevelopment [16]. Although the marker tree arches like a gateway, its reach and interactivity is limited by placement behind a fence, like an illustration of the saga it recounts. Nevertheless the marker tree links memories with today's quotidian. The artist puts historic symbolism in modern commuter context. 'This site marks our transition from residential life to the workplace', Hickman explains [13].

\section{TREE OF TIDINGS, FOREST/JUPITER LIGHT RAIL STATION, GARLAND,}

TEXAS, USA 2002

Resulting from an RFP which specified kinetic sculpture and emphasized multiculturalism, this tree celebrates communication, wind force, and trees, (Fig. 4). Two components rotate independently, as do the butterfly-like wings on the three triangular leaves. Welcoming and safe journey phrases in 32 languages are printed on the leaves. Particularly significant to both the artist and the public is the 
placement of the tree near the entrance to the station platform, site of highest passenger interaction, and also near the station lights to deter vandalism. The free-form metal and glass leaves utilize both enameled and bare surfaces, subject to a weathering patina. It was installed in 2002 , with a US $\$ 30,000$ award to artist Susan Pascal Beran [17].

Located east of Dallas, Garland is served by DART light rail to fulfill its mandate to regionalism. According to DART protocol, values and artistic aesthetics of each community are sought for station design and sculpture, via local input [18]. Originally a center of cotton and onion cultivation; after 1945 food processing, aircraft manufacturing, defense industry, hat and paint manufacturing, and oil well supply developed [17]. Attracted by this developing economy, a multicultural community inmigrated. Thus a citizens committee was appointed. In total, this committee chose the artist to consult on station design with the architects (David B. Hickman, mentioned above), the artistic/ design priorities, the sculpture, and the final overall station design [18-20].

The sculpture is designed, pursuant to DART requirements, to withstand wind forces of 90 miles per hour, as well as pounds per square foot (psf) of the vertical area [21]. To accomplish this, supporting and kinetic mechanisms are aircraft strength, and the glass elements are dichroic, the type used in space shuttles. Internal design utilizes drag coefficient to slow down rotation in high winds [17]. Moving elements purposefully suggest cotton and onions, by the inspiration of the artist: 'These shapes are at once discernable but also universal as plant shapes, so they also suggest leaves, leaf buds, and flowers, depending on the perspective and movement,' explains Beran [17].

At RFP outset, artists had the option of placing two sculptures either on top of power poles or free-standing. As construction progressed, the power pole location dissolved and was replaced by the option of anchoring it in the existing planter boxes (Fig. 4). At the finalist selection phase, when the artists submitted proposal drawings, the requirements morphed to free-standing [21]. The artist's initial submittal proposed one free standing tree at what became its final location. The pole supporting the kinetics paralleled the vertical, tapering poles atop each passenger shelter. The final location was approved by the art committee [17]. In this wind swept plains landscape, trees are a human-built incursion, adaptation, and alteration: windbreaks for farming, shade for picnics, leaves for speaking.

\section{JURASSIC LEAVES, LOUISIANA-PEARL LIGHT RAIL STATION, DENVER, COLORADO, USA, 2006}

This sculpture shelters the entrance to the Louisiana-Pearl light rail boarding platform (Fig. 5). The artist is architect Mark R. Leese. Structural design is by Russ Leffler. It is fabricated by Mike Mancarella in Denver [23]. The infrastructure is painted steel tubing, bent and welded. The top leaf surfaces are oxidized copper sheathing, thus the patina. Stainless steel, riveted to the copper, comprises the underside of the leaves, for 'reflectivity and strength', according to the architect-artist [24].

Three rail routes serve this station. Travelers can ride bicycles along the sidewalk, or transfer to the city bus, which runs north-south to and from downtown Denver. Multimodality derives as the bus intersects several other routes, with two other light rail stations at respective end points, and one park and ride. Impetus for the sculpture was the amelioration of intrusive effects of light rail construction, in tandem with widening highway I-25, which it overlooks. The Louisiana-Pearl station was a 2006 southern extension to downtown Denver light rail. The pavement in the foreground continues as a plaza built over the light rail station beneath it, accessible by elevator and stairs.

Trees, drought-resistant shrubs, and park benches fulfill its organic form, water conservation, and neighborhood landmark concepts and goals. These objectives were developed through public meetings, together with city council and RTD staff input. The city and county of Denver joined for this 
US\$2.5 million public works project. Leese and landscape architect Tom Jump collaborated on the plaza design (Fig. 5) [23-25].

No request for proposals or qualifications was involved in selecting either the sculpture or the plaza design team. Instead, the designers were chosen by the city as on-call consultants to expedite deadlines within the highway widening and light rail construction, in which the plaza became embedded [25]. Deriving from the plaza mandate, the sculpture evolved to fulfill its botanical forms and community enhancement model. The sculpture's protective and functional features were also emphasized by the artist. For example, the leaves' surfaces provide shade and divert rain from the stairwell [24], although commuters can't escape howling wind, rain, snow, sleet, and hail whilst running for their trains.

To the benefit of intermodal transportation environments as well as Denver urban trekkers, the city council approved the sculpture as part of the total plaza cost. The public officials appreciated functionality of its essential cover and canopy for the stairwell, concluding: 'leaves are an example of quality design treatments which Denver Public Works tries to achieve on many of its projects' [25]. Notwithstanding pragmatics, Jurassic leaves' undulating, wind-wafting composition, curvilinear stems, and deciduous leaf tree veins, emulation and exaggeration of nature at the junction with concrete, and even effeminate ephemerality of falling leaves, can be appreciated by passersby.

\section{CONCLUSION}

From these sculptures it's obvious that private entrenchment in public art divests the process of transparency, as seen from the Vancouver and Los Angeles sculptures. Obviously from the Dallas art, standardized processes and local citizen committees beget maximum trust and broad public input into the design. Architect engendered, as well as collaborated art also function in this realm, as shown in the Denver and Los Angeles sculptures. Utilitarian demands do not stifle creativity in transit art; instead, creativity embraces function. Even the plant forms serve dual utilitarian and aesthetic functions. 


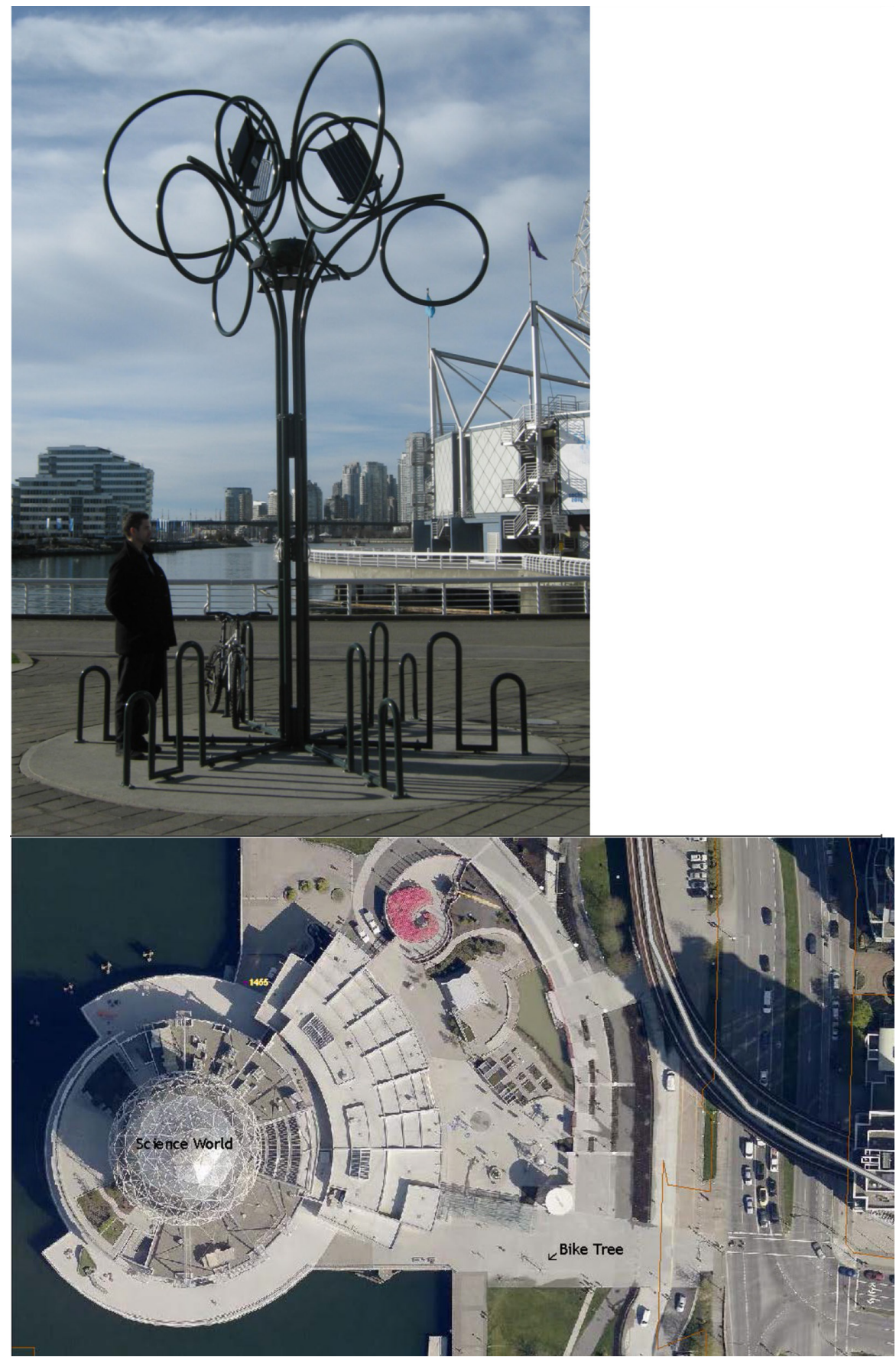

Figure 1: Solar bike tree, Vancouver, BC, city photos. 


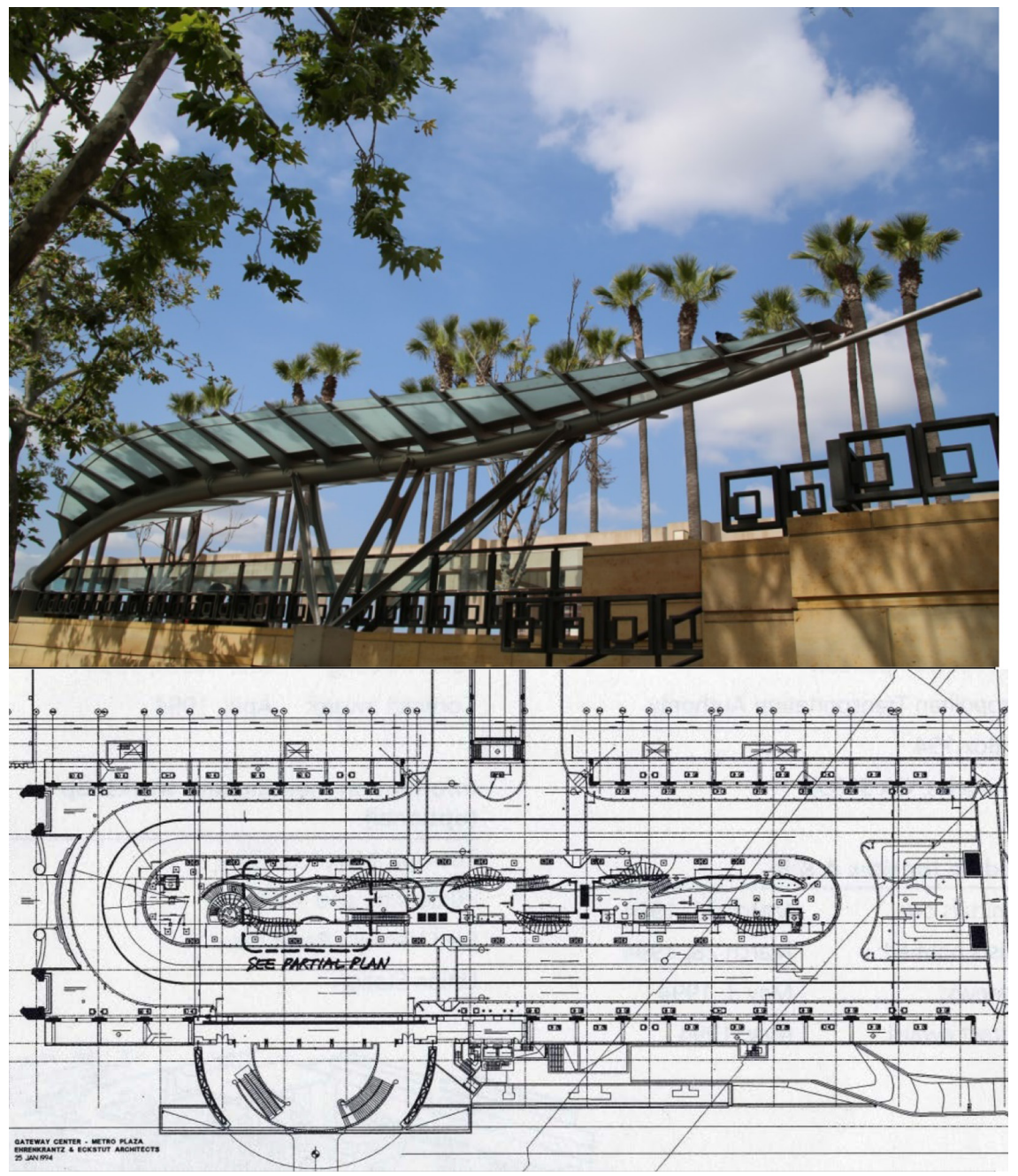

Figure 2: Gateway Plaza, Union Station, Los Angeles, California Photo by Robin Gay Wakeland. 

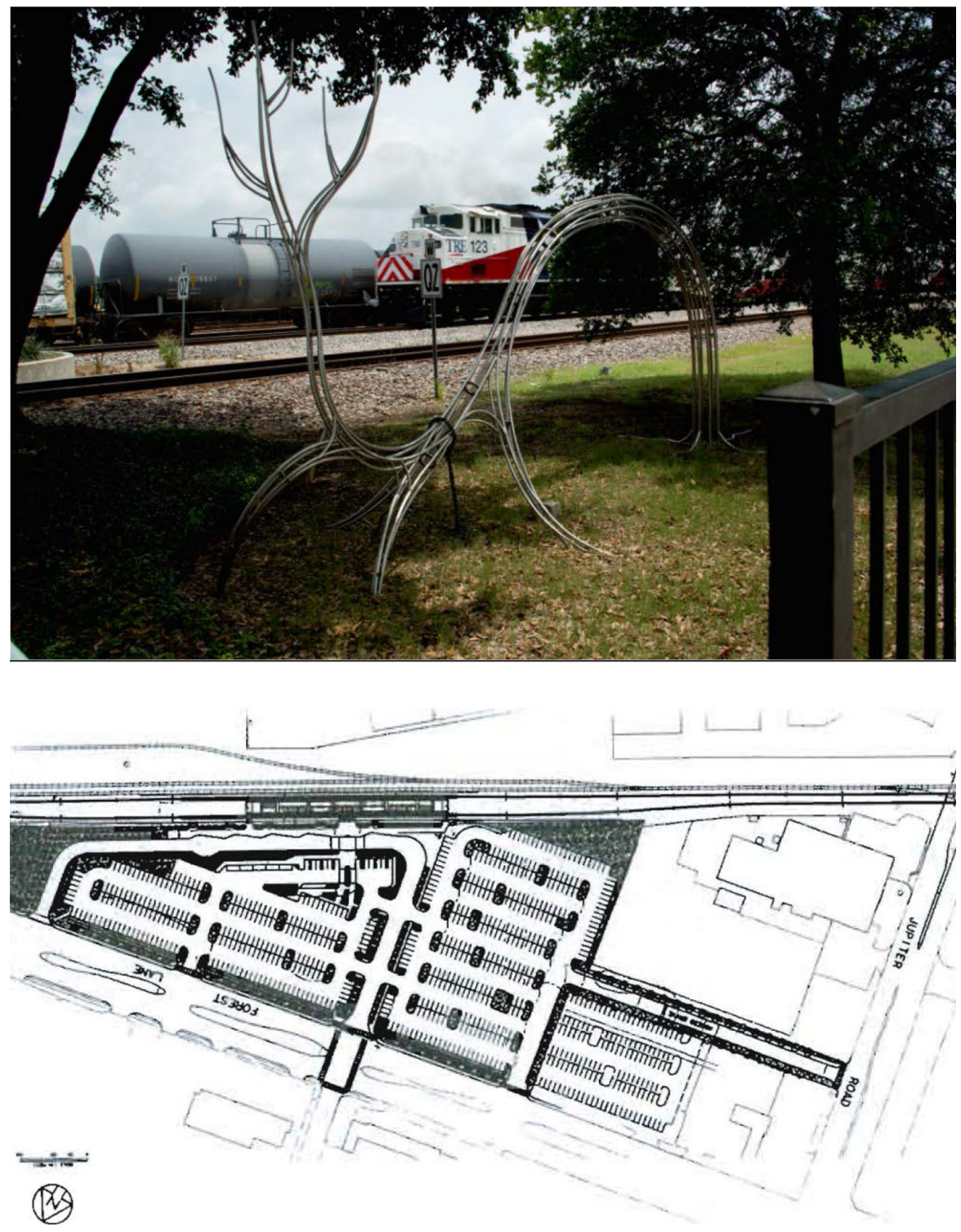

Figure 3: Marker tree, Irving, Texas Photo by Robin Gay Wakeland. 

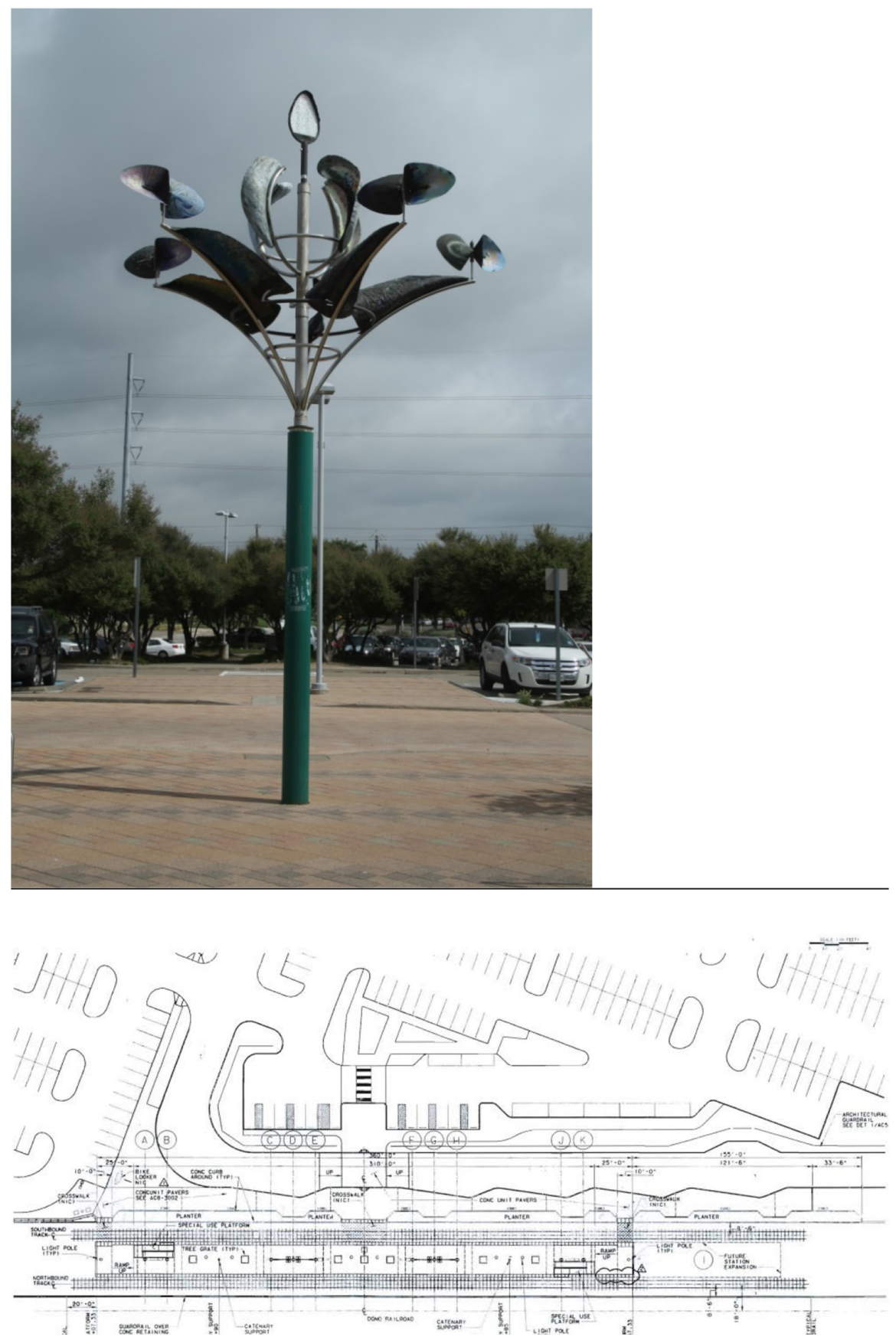

Figure 4: Tree of tidings, Garland, Texas Photo by Robin Gay Wakeland. 

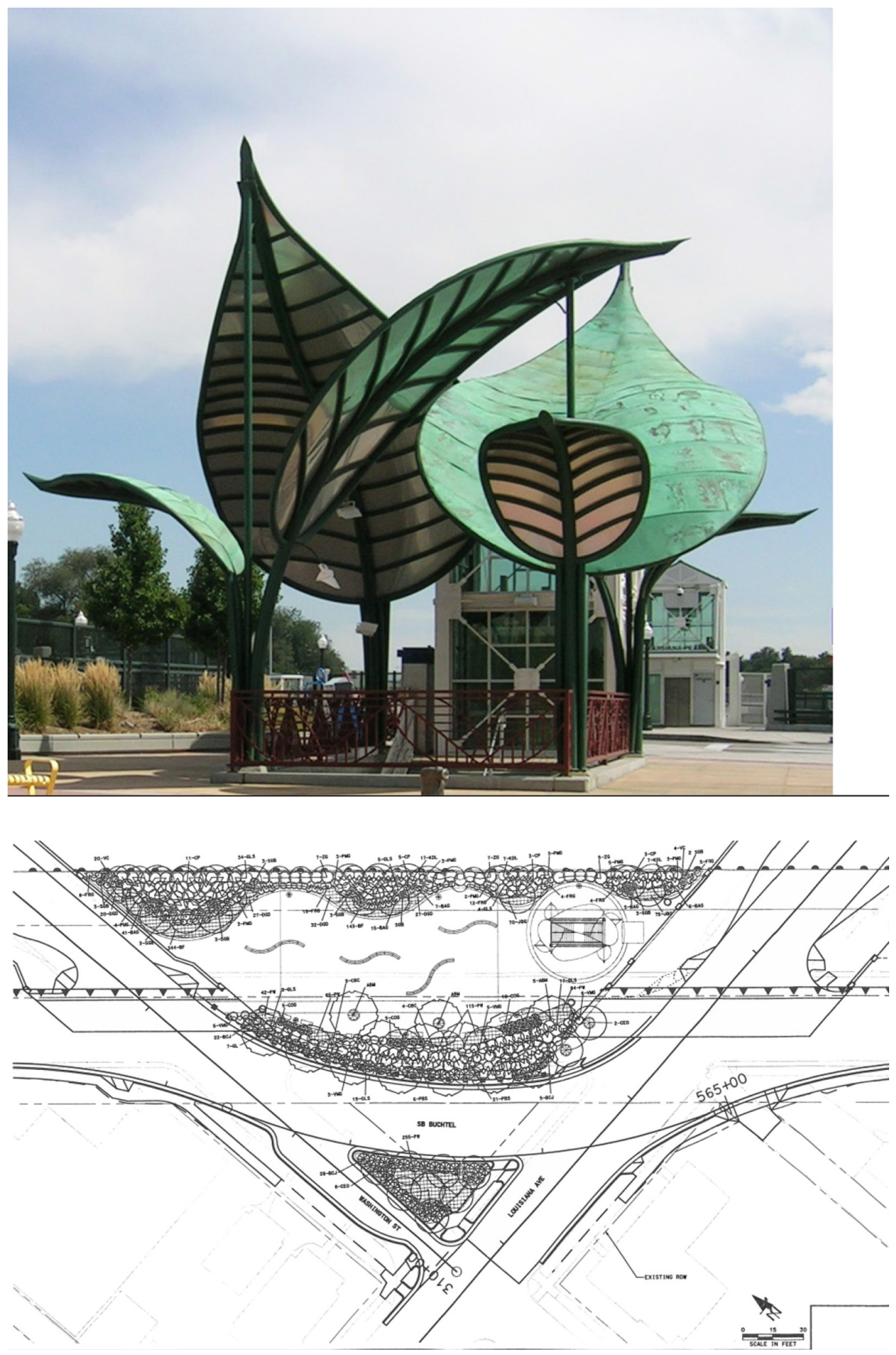

Figure 5: Jurassic Leaves, Colorado, USA. 


\section{REFERENCES}

[1] Science world, http://www.scienceworld.ca/history

[2] Newson, B., Response to author's public records request, 18 June 2014, Public Art Program Manager, Vancouver, BC, Canada.

[3] Newson, B., Response to author's public records request, 6 May 2013, Public Art Program Manager, Vancouver, BC, Canada.

[4] Vancouver, British Columbia, Canada, http://app.vancouver.ca/PublicArt_Net/ArtworkDetails.aspx?ArtworkID=500\&Neighbourhood $=\&$ Ownership $=\&$ Program

[5] Belluce, M., Response author's email, 31 January 2014, Public Art Planner, Vancouver, British Columbia, Canada.

[6] Caltrans, http://transitorienteddevelopment.dot.ca.gov/project/stateViewProjectOverview. jsp?projectId $=10 \& \&$ stationId $=7$

[7] Nakagawa, A., Response to author's public records request, 18 April 2013, Public Art Officer, MTA, Los Angeles, California, USA.

[8] Catellus Corporation, Union Station Gateway Center, Public Art Opportunities, MTA archives: Los Angeles, California, ca. February 1994.

[9] Nakagawa, A., Response to author's public records request, 17 April 2013, MTA Public Art Officer, Los Angeles, California, USA.

[10] Nakagawa, A., Response to author's public records request, 16 April 2013, MTA Public Art Officer, Los Angeles, California, USA.

[11] Thomas, T. \& Fine Art Services, Inc., Union Station Gateway Art Competition Finalists, MTA archives: Los Angeles, California, USA, 1993.

[12] Wadworth, M.L., \& Irving Heritage Society members, Historic Trails Guide, Irving Heritage Society: Irving, Texas, 1988.

[13] Dallas Area Rapid Transit (DART), Solicitation and Award B-99035391, DART: Dallas, Texas, USA, 2 July 1999.

[14] Dallas Area Rapid Transit (DART), http://www.dart.org/riding/tre.asp

[15] Campbell, M., Letter to Irving mayor, DART archives: Dallas, Texas, USA, 29 October 1991.

[16] DART http://www.cityofirving.org/tif2/redevelopment-activity.pdf

[17] Dallas Area Rapid Transit (DART), Solicitation and Award P-1004379, DART: Dallas, Texas, USA, 7 June 2002.

[18] Stanton, N., Letter to Garland mayor, 29 January 1998, DART Chair Person, Dallas, Texas, USA.

[19] Bauman, S., Letters to Garland city manager, 10 February \& 4 March 1998, DART VicePresident, Dallas, Texas, USA.

[20] Garland Art Committee. Forest/Jupiter site visit memo, 23 April 23 1998, Garland, Texas, USA.

[21] Rivero, C., Memo to DART General Engineering Consultants, 25 April 2002, P.E., Charles Gojer and Associates, Inc., Dallas, Texas, USA.

[22] Hodgkins, S., Letter to semi-finalists, 22 February 2002, DART Art Program Manager, Dallas, Texas, USA.

[23] Public relations, Response to public records request, 11 April 2013, RTD-Denver.com, Denver, Colorado, USA.

[24] Leese, M.R., Personal communication, 6, 7 May 2013.

[25] Dorroh, R., Response to public records request, 17 April 2013, Denver Public Works, Engineering Specialist, Denver, Colorado, USA 